\title{
Efficiency of Ladybeetles (Coccinellidae: Coleoptera) in Insect Control
}

\author{
George N. Wolcott ${ }^{1}$
}

\section{INTRODUCTION}

The extraordinary and world-famous success of the control of the cottony cushion scale (Icerya purchasi Maskell) in California citrus groves by the introduction of the Australian ladybeetle (Rodolia or Vedalia cardinalis Mulsant) was in reality such a special instance of the value of biological control as to result in the retardation for as much as a dozen years of progress and investigation of other methods of insect control in California. Citrus growers in particular, and the general public as a whole, were convinced that, if an imported ladybeetle could control one insect pest, some comparable parasite or predator should be equally effective against every other pest. To properly evaluate just how unique and specialized this particular demonstration of the value of biological control actually was, the total evidence of effectiveness of ladybeetles in a similar, comparable insular environment is presented herewith.

\section{DISCUSSION}

\section{HISTORICAL}

The insect fauna of the Island of Puerto Rico in the West Indies, the more eastern of the Greater Antilles, approximately 100 miles long and 30 miles wide, was recorded by the eminent Cuban naturalist, Dr. Juan Gundlach, born in Germany, who collected there in 1873 and 1875. Presumably, almost any insect that he recorded as being present at that time was endemic, as this was long before the planned importation of ladybeetles had even been considered. But, following the discovery of an infestation of the cottony cushion scale in a rose-garden in a suburb of San Juan in 1932, and its rapid dispersion to beefwood, Casuarina equisetifolia, trees and citrus groves, an importation of the Australian ladybeetle demonstrated in how varied an environment it could survive. Annual rainfall along the north coast of Puerto Rico varies from 50 to 90 inches per year, quite different from conditions in the irrigated citrus groves of California. Indeed, the entomogenous fungus, Spicaria javanica, under conditions of high humidity and temperature, caused total elimination of the scale in several citrus groves, while the ladybeetle achieved only commercial control generally during dryer periods.

${ }^{1}$ Entomologist, Remsen, N. Y., U.S.A. 
The only partial effectiveness of the imported ladybeetle is definitely most desirable, for enough scales survive somewhere to serve as food for at least a few beetles. Although very scarce at times, Vedalia has never completely disappeared, as has happened at least twice on the much smaller Island of Bermuda, forcing an appeal for help from Puerto Rico, on the appearance of fresh scale outbreaks. In citrus groves close to the beach at Dorado, exposed to the direct buffetings of the trade winds, the scales continued to survive despite repeated releases of ladybeetles from the laboratory, as apparently some stage of the beetles could not survive under such extreme conditions. But, most surprisingly, somewhat smaller reddish larvae of a previously unknown ladybeetle, Decadiomus pictus Chapin, were found feeding on the scales here: so rare and restricted in its distribution as never to have been noted elsewhere, or found subsequently.

In most striking contrast to the apparently permanent establishment of an Australian ladybeetle, specifically predaceous on an Australian scale insect, which by preference and most commonly occurs on the needles of the Australian pine, Casuarina equisetifolia, consider the condition of the formerly abundant Megilla or Coleomegilla innotata Mulsant, definitely recorded by Dr. Gundlach and presumably endemic. With conspicuous, bright yellow, unspotted elytra, the beetles may feed on pollen grains, and both adults and larvae were repeatedly noted feeding on various kinds of aphids, and most often on the common yellow aphid of sugarcane, Sipha flava Forbes. But as mass infestations of this aphid have become more numerous, especially following the introduction of the very susceptible Uba cane, records of this ladybeetle become increasingly scarce, the last one being in 1940. Presumably the species still exists, but one cannot but wonder why, with increasingly abundant sources of food, and no attempts at insecticidal control of the aphids, it nevertheless has tended to disappear.

What would appear to be a strictly comparable species, Cycloneda sanguinea Linnaeus, with unspotted, orange-red elytra, continues to be abundant, and is most often noted feeding on Sipha flava, but is by no means confined to this one species of aphid. Despite heavy parasitization of the larva by the Braconid wasp, Homalotylus terminalis Say, it appears to be one of the most common, and conspicuous of ladybeetles, of which individuals are often noted in cane fields and on vegetation not closely associated with sources of food. It is almost invariably associated with heavy infestations of Sipha flava, and in one notable case was so abundant as to eliminate the possibility of conducting experimental tests of cyanogas for aphid control.

Yet one never sees outbreaks of yellow aphid effectively controlled by these ladybeetles, the only instances of absolutely complete control being due to extended rainy periods favoring the entomogenous fungi Acrostalag- 
mus albus and $A$. aphidum. For these two oval ladybeetles, one with red elytra, the other with yellow, all conditions would appear to be in favor of Megilla maculata, not known to be attacked by specific parasites, and presumably no more likely to be snapped up by the grass lizards, such as Anolis pulchellus, unless one can imagine that their yellow elytra are more obvious to the lizards than the red elytra of the now much more common Cycloneda sanguinea.

The considerably smaller, endemic, aphid-feeding species, such as Scymnus floralis F., Scymnus roseicollis Mulsant, Hyperaspis festiva Mulsant, and Hyperaspis connectens Thunberg, are quite often noted as one or a few individuals associated with plants of sugarcane, corn, cotton, and some vegetables, but are really of only minor value after aphid infestations have gotten well started. The almost universal necessity for the application of insecticides for the control of Myzus persicae on commercial plantings of eggplant and pepper, and more recently on tobacco, is a sad commentary on the ineffectiveness of ladybeetles in the control of at least this one aphid, which appears unaffected by any parasite or predator. Comparatively little effort has been expended on the specific introduction of aphid-eating ladybeetles, the one obvious exception being Coelophora inaequalis $\mathrm{F}$., originally from Australia, sent to Puerto Rico from Hawaii. It appears to be established, as adults have been collected from the extreme limits of the Island, but not in sufficient numbers to prove its value.

\section{PLANNED INTRODUCTION}

The first purposeful and planned introduction of a ladybeetle into Puerto Rico was of the socalled Australian "mealybug-destroyer", Cryptolaemus montrouzieri Mulsant, in the expectation that it would feed on the mealybugs of sugarcane. These mealybugs, however, occur almost exclusively at the nodes under the leaf-sheaths, tightly wrapped around the stalks of cane, where they are well protected against external influences. By the time that the individual leaf-sheath has matured and loosened, the female mealybug has also matured, and the crawling young of the succeeding generation have disappeared. In captivity Cryptolaemus beetles readily fed on hand-collected mealybugs from sugarcane, and not only survived, but thrived. But when released in cane fields they migrated to other environments, and were later found feeding on exposed mealybugs and soft scale insects. They were so conspicuously successful in greatly reducing the numbers of these unanticipated hosts that records of outbreaks are rare in the years following the introduction.

The very limited space under the base of a leaf-sheath of sugarcane so often infested by mealybugs actually does provide room for a surprisingly large ladybeetle, Hyperaspis trilineala Mulsant, present in Trinidad and 
Barbados. Repeated introductions into Puerto Rico have been made, but apparently not in sufficient numbers to secure establishment of the species, or at least, none has been recovered in the field.

Of all the subsequent importations of ladybeetles none has been more successful in accurately controlling the preferred, or most desired, host of which control was expected, than that of Cladis nitidula Fabricius. Although a surplus of the beetles may be found feeding on other scale insects, this beautiful yellow ladybeetle with bright, iridescent green elytra was specifically selected as a predator on the scales, Asterolecanium bambusae Boisduval of the trunks of bamboo. Although so conspicuously beautiful in green and yellow, it accurately matches the background of the bamboo trunks, and almost invariably one will find larvae or adults in almost every cluster of bamboo inspected.

Against the background of the shining, polished, dark-green trunks of Bambusa vulgaris, the ladybeetles are not at all conspicuous, except possibly when in motion. Apparently the lizards inhabiting the bamboo clumps do not habitually feed on them, or their spiny, black, yellow, and white larvae, nor on the reddish-yellow pupae marked with black, for Cladis continues to occur in moderate abundance, over at least the observed period of years, on almost every bamboo clump of the Island. It has greatly reduced the scale population, possibly having attained a state of ecological balance, and only locally and temporarily exhausting its food supply. At times the preferred bamboo clusters may produce a surplus of beetles which have been observed on Bougainvillea bushes, absolutely eliminating heavy infestations of Orthesia praelonga, but this is exceptional. Indeed, this may be considered possibly the most successful of introductions in Puerto Rico: attacking and greatly reducing the abundance of the scale from which it was collected in Martinique and Trinidad, but with a small surplus of scales always present, so that the food supply is not exhausted and the beetle starved into extinction.

\section{SPREAD OF THE ENDEMIC LADYBEETLE Chilocorus cacti L.}

Regardless of what in Cuba may be the vital factors resulting in limiting the abundance of the endemic ladybeetle, Chilocorus cacti L., they would appear largely inoperative when these aggressive beetles were brought to Puerto Rico. The trade winds of the West Indies, blowing almost constantly from the northeast, have apparently restricted the previous natural distribution of this beetle to Cuba, the most western of the Islands. But rapidly becoming abundant in Puerto Rico, explosively by its own efforts, and presumably helped by the direction of the trade winds, it not only reached the little Island of Mona, but also the much larger major Island of Hispaniola, dispersing from one end to the other. Definitely not omnivo- 
rous, but feeding on a wide variety of scale insects, and possibly even the yellow aphid of sugarcane, Sipha flava Forbes, it has many times been observed to stop infestations of the coconut scale, Aspidiotus destructor Signoret, and the West Indian peach scale, Pseudalacaspis pentagona Targioni, a major pest of papaya at lower elevations, and of peach trees in the mountains of Haiti.

Indeed, Chilocorus cacti, is much too effective for its own good, an engulfing wave of its gregarious larvae so entirely and absolutely destroying every scale insect on a papaya or peach tree that none survive to serve as food for the species. As was related in more detail at the Montreal Congress $(1),{ }^{2}$ a dozen or 15 years elapsed after their initial introduction into Puerto Rico before not only the more obvious of host scale insects, but also the beetles, completely disappeared, and a subsequent period elapsed before a small colony of one scale reappeared. Only the lapse of time will indicate whether any other species of scale insect, or the ladybeetle itself, survived.

\section{NONE GENERALLY EFFECTIVE TO CONTROL APHIDS COMMERCIALLY}

All data regarding these ladybeetles, and all the others known to exist on the Island, are recorded in the inclusive account of "The Insects of Puerto Rico" (2), but the conclusions to be drawn from their summarization are new. It now becomes obvious that, despite all the attention devoted to the individual ladybeetles, both the endemic and introduced, none is generally effective in the commercial control of aphids. The socalled green peach aphid, Myzus persicae, which has recently attained such importance as a pest of tobacco, is attacked by none, and is virtually insusceptible to biological control. One must also conclude that endemic ladybeetles have a very limited commercial usefulness, each species having long previously attained a status of ecological equilibrium, not readily disturbed, and for the most part unaffected by the arrival of any new species of scale insect.

Since most probably the flora of Puerto Rico originally did not include the coconut palm tree, it may be presumed that the specific scale insects of the coconut palm were unwittingly brought in with the original (or subsequent) introduction, but without any corresponding ladybeetle predator from the country of origin. No quarantine inspection of grapefruit trees prevented the introduction of scale insects of citrus. Recent times have witnessed the introduction on Mona Island of the cottony cushion scale on nursery seedlings of the Australian pine, Casuarina equisetifolia, just when these trees were becoming most popular in Puerto Rico and were being most widely dispersed. In each case ladybeetles specifically attacking particular scale insects, when freed of their previous enemies (admittedly

${ }^{2}$ Italic numbers in parentheses refer to Literature Cited, p. 172. 
not including the native lizards of Puerto Rico) and brought from their country of origin in sufficient numbers to assure establishment, may be spectacularly effective in their new environment.

Of the numerous introductions of ladybeetles in most recent times, most failed of survival, or at least no indication of their presence can be found after the first reports of their release and establishment. As with all bewildered, helpless immigrants in a new environment, the factors affecting survival are numerous. These may not be at once apparent, although the omnipresent lizards, Anolis cristatelus, one of which inhabits each fence-post, and nearly every tree in Puerto Rico, are too conspicuous to be ignored, and account for the mortality of most of the beetles in every release in the few minutes before they can take cover. More introductions have apparently failed than those which succeeded, even though the outcome could never have been predicted.

One may thus summarize the results of ladybeetle introductions in Puerto Rico as consisting of a few obvious and most conspicuous successes in the commercial control of mealybugs and scale insects, but none of aphids. Some of these are of most permanent value when destruction of the hosts fails of being total, always leaving an ample margin for their later subsistence. On the other side of the picture are the much more numerous (but unpublicized) failures of ladybeetles to survive the first few months or year after introduction. In the control of major economic pests, the effect of the endemic forms is practically negligible, one at least of which for no apparent reason in recent years has actually disappeared.

\section{SUMMARY}

A most remarkably effective control and often total elimination of some scale insects and exposed mealybugs by ladybeetles-Coccinellidae: Coleoptera-occurred on the tropical Island of Puerto Rico, affecting such introduced plants as coconut palm, grapefruit, bamboo, and Australian pine. No comparable control resulted of aphids, either by introduced ladybeetles or endemic species, presumably in ecologically balanced adjustment to their environment. Indeed, the native ladybeetles became scarce, or tended to disappear. None feeds on Myzus persicae, a major pest of eggplant and pepper, and most recently on tobacco. No instance of effective control of the yellow aphid of sugarcane, Sipha flava, due to ladybeetles, has been observed.

\section{RESUMEN}

El mas extraordinario y eficaz combate y la casi total eliminación de las queresas y chinches harinosas ocurrió en la isla tropical de Puerto Rico cuando éstas atacaban plantas introducidas, tales como el coco, toronjas, 
bambues y pinos australianos. En los pulgones no hubo un control comparable debido a que en las cotorritas introducidas o endémicas ocurrió un balance ecológico de ajuste al medio ambiente y su eficiencia se redujo notablemente. Se ha observado que las cotorritas nativas escasean y tienden a veces a desaparecer. Ninguna de ellas se alimenta de Myzus persicae, la plaga mayor de las berenjenas, los pimientos y recientemente del tabaco. No se ha notado un control eficaz del pulgón amarillo de la caña, Sipha Aava, debido a la acción de las cotorritas predatoras.

\section{LITERATURE CITED}

1. Wolcott, G. N., The evanescence of perfect biological control, Proc. 10th Inlernational Congress of Enlomology 41956 (1958) 511-3, Montreal, Canada.

2. Wolcott, G. N., Insects of Puerto Rico, J. Agr. Univ. P. R., 32 (1-4) 1-975. 